\title{
LidSuperior X Lid: A Case On Launching A New Patented Cup Lid In The United States
}

P. K. Shukla, Chapman University, USA

Monica Shukla, Brandman University, USA

Yatri Shukla, Chapman University, USA

\begin{abstract}
This case reviews the background of a new entrepreneurial firm, LidSuperior ${ }^{*}$ on the launching of a new patented hot beverage cup lid in the United States for disposable hot beverage cups. The United States hot beverage cup lid industry is highly concentrated with a few major competitors who have dominated the market in sales volume over several years. One brand in particular, the Dart "Solo Traveler" lid has been the market share leader for several years. LidSuperior designed, after multiple preliminary design attempts, an innovative $X$ lid that enhances aroma of hot beverages, reduces the possibility of spills, and increases safety in drinking and transporting a hot beverage cup. LidSuperior's lid design also allows room on the side of the lid for advertising or shared lid-costs with co-marketing partners. The firm secured a patent on the design and functionality of the lid as claimed benefits were validated with independent marketing research sensory tests. LidSuperior is working on developing a marketing plan to introduce the hot beverage lid within the United States to be later followed by a cold beverage lid design and launch.
\end{abstract}

Keywords: Marketing Plan; Product Launch; Beverage Lid Industry

Suggested Courses: Entrepreneurship; Principles of Marketing; Operations Management; Project Management

\section{EXECUTIVE SUMMARY}

- Firm description: Details of the company, the main protagonists and the major conflict or obstacles to be overcome

- Company name: LidSuperior, Inc.

- Location: Southern California

- Field: Disposable hot and cold beverage cup lids

- Established: 2013 Estimated Revenues: still at startup stage at time of case

- Main Protagonists: Sam Designer ${ }^{*}$ Wendy Designer*

- Major Conflict/Obstacles: How a new entrepreneurial firm can launch a new product in a marketplace dominated by well-established larger volume leading brands.

\section{GOALS AND OBJECTIVES OF THE CASE}

Students will learn the following from this case analysis:

- How successful entrepreneurs recognize opportunities often missed by others.

- The importance of proper marketing research and testing to validate claimed benefits put in a patent application and the importance of analyzing marketing share data.

- Hot and cold beverage cup lid industry factors.

- The importance of a proper marketing plan and marketing mix for launching a new product into an established marketplace.

* Disguised name of firm 
The case and case questions have been pre-tested and revised based upon feedback of instructors/students.

\section{So What?}

This will be an interesting case for both business students and also practitioners. The protagonists/firm, industry, and broad appeal of hot beverage drinking among readers of the case will lead to an informative case/discussion.

\section{BACKGROUND OF THE INDIVIDUAL AND LIDSUPERIOR}

Sam Designer received a Bachelor's degree in Business Administration from a private university in Southern California. After graduating from college, both Sam Designer and his wife Wendy attended an intensive culinary chef training program. Sam enjoyed drinking hot coffee but found a distinct difference in aroma and overall sensory experience when drinking from a coffee mug and drinking from a disposable cup with a plastic lid. Using the skills acquired from the chef program, Sam and Wendy started working on the design of a new and improved hot beverage disposable cup lid that would enhance aroma, reduce spills, and one that would be safer to drink from and safer to transport. They started up an entrepreneurial venture, LidSuperior to launch their newly designed lid for disposable hot and cold beverage cups. LidSuperior did sensory test marketing research to validate claims of superiority and received a patent on their hot beverage lid. LidSuperior gathered marketing research data on industry sales for analysis (The Freedonia Group, Inc. 2013).

\section{BACKGROUND OF THE INDUSTRY AT THE TIME OF FOUNDING AND SALES FORECAST}

\section{Market Segments, Key Competitors/Market Shares, and 2016 Sales Potential Forecast}

A. Cup and Lid Demand by Establishment and Application in the United States, 2013

Foodservice Cup \& Lid \$ Demand by Establishment

\section{$\$ 5.4$ Billion in 2013 \\ 52\% Quick Service Restaurants \$2.79 Billion \\ $15 \%$ Coffee \& Snack Shops \$ \$ $\quad \$ 1$ Billion \\ $33 \%$ Other \$1.80 Billion}

(retail stores, sports and recreation venues, institutional establishments, company cafeterias, lodging and hospitality establishments, food trucks)

Foodservice Cup \& Lid Unit Demand by Application

228 Billion Units in 2013

$35 \%$ Hot Beverages

79.4 Billion Units

$18 \%$ Carbonated Soft Drinks

40.3 Billion Units

$47 \%$ Other (non-carbonated cold)

108.2 Billion Units

cents/unit 2.4 [228 billion units @ \$0.024/unit= $\$ 5.472$ billion] 
Figure 1. Foodservice Cup and Lid Demand by Establishment

\begin{tabular}{|c|c|c|c|c|c|}
\hline \multicolumn{6}{|c|}{ Foodservice Cup \& Lid Demand by Establishment (million dollars) 2003 - 2023} \\
\hline Item & 2003 & 2008 & 2013 & 2018 & 2023 \\
\hline Eating \& Drinking Establishments (000) & 514 & 574 & 608 & 646 & 668 \\
\hline $000 \$$ cups \& lids/establishment & 6.6 & 7.8 & 8.9 & 10.2 & 11.9 \\
\hline Foodservice Cup \& Lid Demand & 3404 & 4504 & 5395 & 6590 & 7980 \\
\hline Quick Service Restaurants & 1795 & 2367 & 2791 & 3361 & 4007 \\
\hline Coffee \& Snack Shops & 472 & 660 & 808 & 1022 & 1275 \\
\hline Other & 1137 & 1477 & 1796 & 2207 & 2698 \\
\hline \% foodservice & 73.2 & 70.1 & 67.0 & 65.9 & 64.9 \\
\hline Total Cup \& Lid Demand & 4652 & 6423 & 8055 & 10000 & 12300 \\
\hline
\end{tabular}

Source: The Freedonia Group, Inc. 2013.

Figure 2. Foodservice Cup and Lid Demand by Application

\begin{tabular}{|c|c|c|c|c|c|}
\hline \multicolumn{6}{|c|}{ Foodservice Cup \& Lid Demand by Application (billion units) 2003 - 2023} \\
\hline Item & 2003 & 2008 & 2013 & 2018 & 2023 \\
\hline Foodservice Cup \& Lid Demand & 191.8 & 211.7 & 227.9 & 253.7 & 279.9 \\
\hline Hot Beverages & 57.0 & 71.0 & 79.4 & 90.4 & 101.7 \\
\hline Carbonated Soft Drinks & 41.6 & 41.4 & 40.3 & 40.0 & 39.8 \\
\hline Other & 93.2 & 99.3 & 108.2 & 123.3 & 138.4 \\
\hline Cents/Unit & 1.8 & 2.1 & 2.4 & 2.6 & 2.9 \\
\hline Foodservice Cup \& Lid Demand (mil \$) & 3404 & 4504 & 5395 & 6590 & 7980 \\
\hline
\end{tabular}

Source: The Freedonia Group, Inc. 2013

B. Market Share of Lid Suppliers, 2013

$1^{\text {st }}$ Tier Competitors: [Combined 35\% of market share]

$20.3 \%$ Dart Container Corporation (Solo)

8.3\% Reynolds Group Holdings

$6.6 \%$ Georgia Pacific (Koch Industries)

$2^{\text {nd }}$ Tier Competitors: [Combined 14\% of market share]

4.3\% Berry Plastics Corporation

$3.7 \%$ International Paper Company

$3.1 \%$ Huhtamaki (Finland)

$3.1 \%$ New WinCup Holdings

$3^{\text {rd }}$ Tier Competitors: [Combined 50.4\% split over 43 producers]

$50.4 \%$ Others in a fragmented industry (regional and smaller segment suppliers) 
C. Estimation of LidSuperior Market Share in 2016

Cup and Lid Demand Estimated by Establishment and Application in the United States, 2016 (2016 values estimated by taking average of 2013 and 2018 values):

Foodservice Cup \& Lid \$ Estimated Demand by Establishment

\$ 5.9925 Billion Estimated in 2016

\section{$\underline{\text { LidSuperior X Lid }}$}

$52 \%$ Quick Service Restaurants

$15 \%$ Coffee \& Snack Shops

$33 \%$ Other*

$\$ 2.002$ Billion hospitality establishments, food trucks)

\section{Foodservice Cup \& Lid Unit Estimated Demand by Application}

\section{$\underline{\text { LidSuperior X Lid Estimation (\$) }}$}

240.8 Billion Units Estimated in 2016

$35 \%$ Hot Beverages

$18 \%$ Carbonated Soft Drinks

47\% Other (non-Carbonated cold)

$$
\begin{array}{ll}
\text { 84.9 Billion Units } & =\$ 212.25 \text { million } \\
\text { 40.15 Billion Units } & =\$ 100.38 \text { million } \\
115.75 \text { Billion Units } & =\$ 289.38 \text { million } \\
& =\$ 602.01 \text { million }
\end{array}
$$

cents/unit 2.5 [240.8 billion units @ $\$ 0.025 /$ unit= $\$ 6.02$ billion]

Foodservice Cup \& Lid \$ Estimated Demand by Establishment- LidSuperior

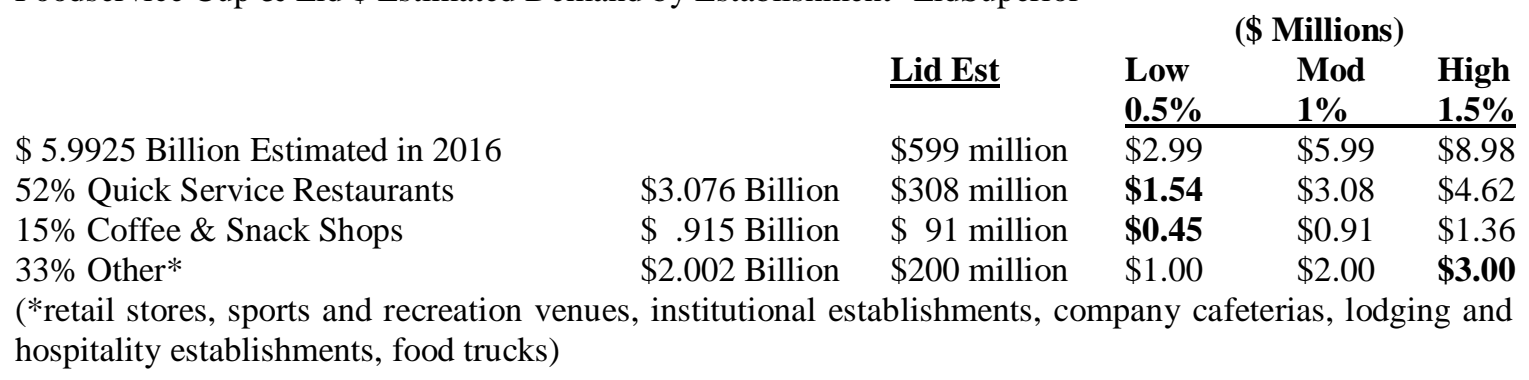

\begin{tabular}{|c|c|c|c|c|}
\hline & & & Million & \\
\hline & $\underline{\text { Lid Estimation (\$) }}$ & Low & Mod & High \\
\hline 240.8 Billion Units Estimated in 2016 & & $0.5 \%$ & $1 \%$ & $1.5 \%$ \\
\hline $35 \%$ Hot Beverages & $\$ 212.25$ million & $\$ 1.06$ & $\$ 2.12$ & $\$ 3.18$ \\
\hline $18 \%$ Carbonated Soft Drinks & $\$ 100.38$ million & $\$ 0.50$ & $\$ 1.00$ & $\$ 1.50$ \\
\hline $47 \%$ Other (non-Carbonated cold) & \$289.38 million & $\$ 1.44$ & $\$ 2.89$ & $\$ 4.34$ \\
\hline & $=\$ 602.01$ million & $\$ 3.01$ & $\$ 6.02$ & $\$ 9.03$ \\
\hline
\end{tabular}

The values identified with bold are the most likely. LidSuperior estimates by establishment type at 18 months out from launch.

Foodservice Cup \& Lid Unit Estimated Demand by Application- LidSuperior

The values identified with bold are the most likely. LidSuperior estimates by application type at 18 months out from launch. 


\section{LIDSUPERIOR MARKETING PLAN AND MARKETING MIX FACTORS}

\section{Product}

LidSuperior X lid has verified and patented design advantages such as better aroma, flow control pinch on sip opening in lid, and logo/advertising space compared to the Viora Lid and Dart Solo Traveler Lid. Figure 3 shows illustrations of these lids.

Viora Lid is owned by Vaporpath (most similar new patented design claiming superior aroma and targeted to "third wave" coffee shops) and Dart's Solo Traveler Lid (the most similar designed lid widely distributed in foodservice) is the leading market share brand with a comparable design. Viora Lid sends sample packages to those interested in purchasing supplies from Viora Lid. LidSuperior's second lid to be designed and tested for superiority is the LidSuperior cold beverage lid aimed at the significant $65 \%$ cold beverages segment.

Figure 3. LidSuperior X Lid on left and Primary Distributed Dixie Lid on right

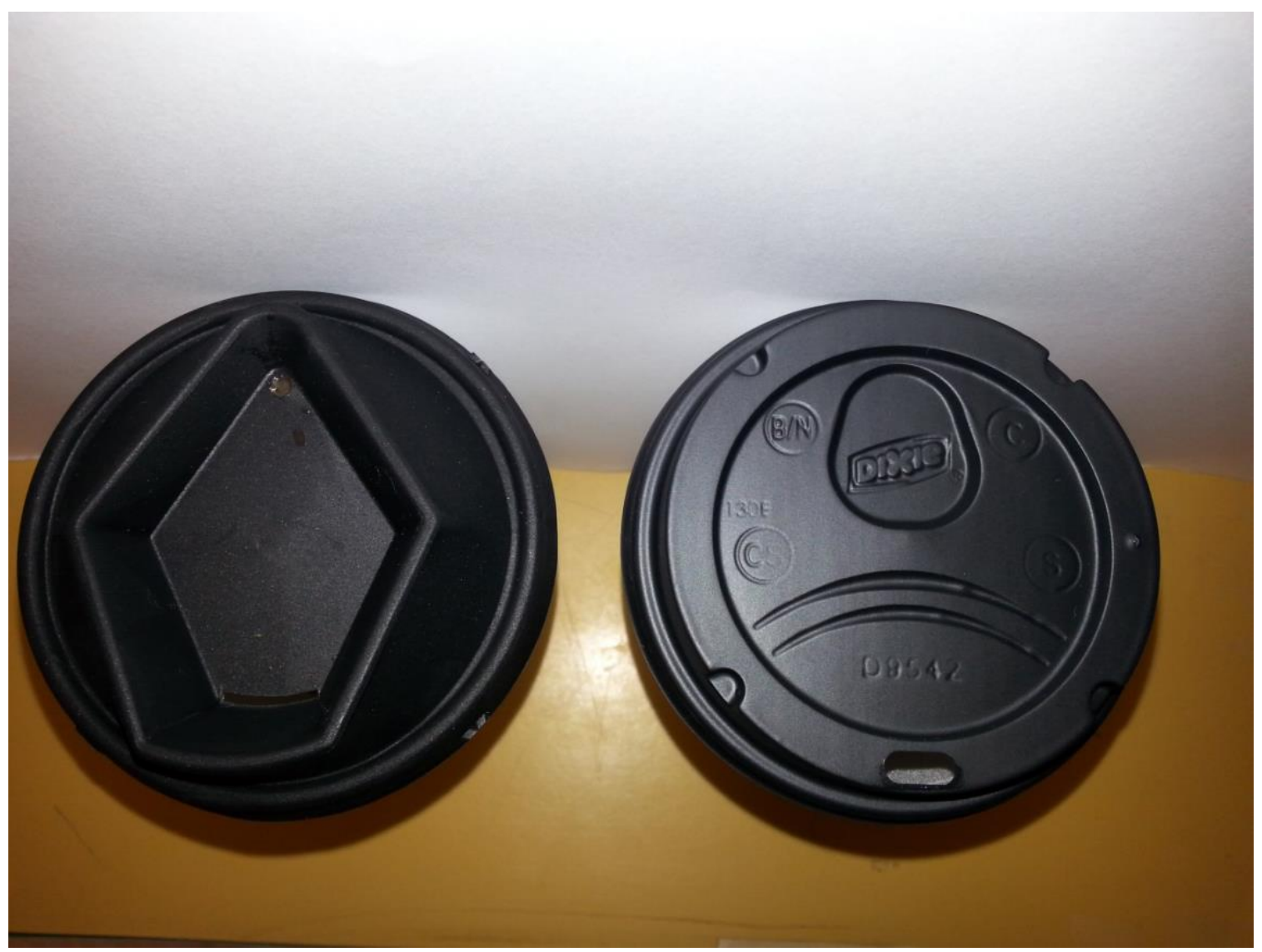

\section{Price}

Dart Solo Traveler Lid price is estimated at 3 to 3.5 cents a lid for 12, 16, 20 or 24 ounce lids in bulk quantities of 1,000 plus ( 3.5 cents if an order of 1000 lids and 3 cents if 5000+ lids) ordered on webstaurant.com. The Dart Solo Traveler Lid was found in only two standard colors- white and black.

Viora Lid is estimated at 6 cents a lid quoted in news release articles from Vaporpath. From all articles reviewed, the Viora lid comes in a standard 12 ounce size lid and a standard black color. 
The high end disposable lids with reclosing feature are estimated at 10 cents a lid quoted in news release articles from Vaporpath. I was able to locate some Solo coffee lids that allow open and reclosing a hinged flap without the aroma enhancing design for 7 cents each (pack of 100 lids) on webstaurant.com

Viora Lid is quoted in news release articles as targeting the mid-range price currently with limited volume production runs aimed at premium third wave coffee shops charging $\$ 4$ for coffee. They have raised $\$ 1,100,000$ in investments and plan to lower their production costs and prices as they expand to more foodservice outlets.

LidSuperior will not win a price war against Dart's Solo Traveler Lid nor is it recommended that LidSuperior try to engage in a price war against Viora Lid as they are gaining additional volume in product runs and efficiency gains to drive their prices down. LidSuperior could focus on superior features over Viora Lid and the added promotional aspects of logo or advertising. The lid could be priced at 9 cents per lid to gain market traction, trial, and to increase production run volume if the buyer is not getting any co-marketing cost split with the advertiser on the lid. If there is co-branding or co-marketing on the lid with advertising, then the lid could be priced higher at 10 to 12 cents a lid as additional costs are split upon the food source outlet and the advertiser. LidSuperior should have prominent display of LidSuperior ${ }^{R}$ clearly visible along with contact point website.

\section{Place}

Dart Solo Traveler is widely distributed at foodservice outlets and has long term established supplier contracts/relationships over the last 30 years.

Viora Lid is targeting premium coffee shops and "third wave coffee shops" where the target demographics are younger, more educated, more tech savvy, urban area drinkers willing to pay more for better tasting and better aroma coffee.

\section{Promotion}

Dart's Solo Traveler Lid does not need promotion due to its market share leadership position in the industry and repeat sales just due to habit formation and annual supplier contract renewal. The main selling points for their lid is- low cost, proven acceptance close to 30 years since 1986, record of safety proven over decades, customer acceptance. Their main vulnerability is stale design and no space for logo/advertising.

Viora Lid introduced their lid April 25, 2014 at the Specialty Coffee Association of America annual trade conference held in Seattle. This tradeshow is attended by premium coffee shops and "third wave coffee shops." Viora Lid promotes their lid as having better aroma (like drinking coffee from a coffee mug with better aroma), less spill (they have an interesting video showing a shake and spill test of their lid compared to traditional lids), and a much improved design over the 30 year old stale Dart Solo Traveler Lid design. They are targeting younger, more educated, tech savvy coffee drinkers who are willing to pay for a premium cup of coffee. The coffee shop buyers, in most cases pass on the additional lid cost to customers willing to pay more for the better aroma or absorb the incremental additional 3 cent added cost per lid over prior cheaper suppliers from their high profit margin from selling a four dollar coffee drink. Viora is trying to leverage their location in Seattle to expand distribution in the region and to gain information technology firm wealthy founders and managers to invest in Vaporpath ( $\$ 1,100,000$ raised so far from SEC filings). The main promotion approach for Viora Lid is to get articles to publicize them, drive potential buyers to their website, and then send a free sample package of five cups and five lids.

\section{QUESTIONS FOR STUDENTS}

The purpose of the case study is to let you apply the concepts you've learned when you analyze the issues facing a specific company. To analyze a case study, you must closely examine the issues in which the company is confronted, explain the overall picture of what is happening to the company and then re-analyze several times more to discover and grasp the specific problems. Once you complete this analysis, you will have a full picture of the way the company is operating and be in a position to evaluate the potential of its strategy in this industry. Thus, you will be able to make recommendations concerning the pattern of the company's future actions. 


\section{What are the positives and negatives of entering into this industry at the time of the case in 2016 ?}

Some of the positives include: high dollar volume in sales, wide variety of lid establishments, wide variety of lid applications, consumer acceptance of using disposable lids, and forecast growth of industry.

Some of the negatives include: well established competitors, high volume requirements to get economies of scale to reduce cost per unit, and difficulty of a startup to reach national geographic scope.

2. Assess industry Threats and Opportunities using Porter's Five Forces Industry Analysis Model. Do you conclude though the Porter Five Forces Analysis that the company is a go or no-go recommendation for market entry?

Threat of Entry into industry: Low due to well established firms and high volume required to get economies of scale. Bargaining Power of Suppliers: High. Few suppliers exist within the United States to produce custom design lids in the United States, more suppliers exist in China but there may be concerns by startups in protecting intellectual property even with a patent.

Bargaining Power of Buyers: High. With a few major buyers (like Starbucks and McDonalds), buyers have high bargaining power.

Rivalry Among Competitors: High, primarily on low price not innovative design.

Threat of Substitutes: Low, other than drinking hot beverages in a coffee mug, lids are required for disposable hot beverage cups.

After doing a Porter Five Forces analysis, most students would conclude not to enter, but entrepreneurial students may argue that despite high risks, there are high potential gains to justify LidSuperior's entry into the market.

\section{What do you see as the strengths and weaknesses of LidSuperior X Lid in this industry?}

Strengths- patent, innovative design, improved aroma, reduced spills, increased safety in drinking, increased safety in transporting hot beverage cups, and options to license out patent use, or option to sell patent and firm.

Negatives- despite chef training of Sam Designer, limited managerial experience at establishments where hot beverage cups and lids are used, lack of name recognition, brand unknown and untested, resource constraints in labor and capacity of output from suppliers contracted to custom design the lid.

\section{AUTHOR BIOGRAPHIES}

Dr. P. K. Shukla is Associate Professor of Management and prior Vice Chancellor of Entrepreneurship at Chapman University in Orange, California. He received his Ph.D. from the University of California, Los Angeles and provides consulting services to business firms.

Dr. Monica Shukla is Associate Dean of the School of Business and Professional Studies at Brandman University in Irvine, California. She received her Ph.D. from Chapman University.

Yatri Shukla, EMBA and M.ScFSN is an adjunct professor at Chapman University. She received an Executive M.B.A. and a Master's of Science degree in Food Science and Nutrition from Chapman University.

\section{REFERENCES}

Freedonia Group Publishers (2013). The beverage cup and lid industry. Industry Study Report 1876. Retrieved from The Freedonia Group, a division of marketresearch.com, Cleveland, Ohio. 


\section{SUGGESTED REFERENCES FOR STUDENTS TO ANSWER QUESTIONS}

Roemmele, B. (2015, April 3). Why one kind of disposable coffee cup lid dominates all the rest. Retrieved from https://gizmodo.com/why-one-kind-of-disposable-coffee-cup-lid-dominates-all-1695511005

Twilley, Nicola (2011, May 9). The rise of the plastic, disposable coffee cup lid. Retrieved from

https://www.theatlantic.com/technology/archive/2011/05/the-rise-of-the-plastic-disposable-coffee-cup-lid/238573/ 